Canadian

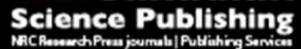

Canadian Journal of Forest Research Revue canadienne de recherche forestière

\title{
The state of innovation in the British Columbia value-added wood products sector: The example of chain of custody certification
}

\begin{tabular}{|r|l|}
\hline Journal: & Canadian Journal of Forest Research \\
\hline Manuscript ID & cjfr-2016-0207.R1 \\
\hline Manuscript Type: & Article \\
\hline Date Submitted by the Author: & 07-Jun-2016 \\
\hline Complete List of Authors: & $\begin{array}{l}\text { Gilani, Haris; University of British Columbia, Department of Forest } \\
\text { Resources Management } \\
\text { Kozak, Robert; Department of Wood Science, } \\
\text { Innes, John; University of British Columbia }\end{array}$ \\
\hline Keyword: & $\begin{array}{l}\text { Innovation, Value-added wood products, British Columbia, Canada, Chain } \\
\text { of custody certification, Forest products marketing }\end{array}$ \\
\hline \multicolumn{2}{|c}{} \\
\hline
\end{tabular}

\section{SCHOLARONE" \\ Manuscripts}


1 The state of innovation in the British Columbia value-added wood products sector: The 2 example of chain of custody certification

3 By Haris R. Gilani ${ }^{1}$, Robert A. Kozak ${ }^{2}$, John L. Innes ${ }^{3}$

4 ABSTRACT

5 This paper investigates the practices of the value-added wood products industry in British

6 Columbia with respect to innovativeness using the results of an online survey. The survey

7 employed an indirect self-evaluation scale to assess the propensity to create and (or) adopt new

8 products, processes and business systems. Using chain of custody certification as an example of

9 business systems innovation, this study also investigated the attitudes of the value-added wood

10 products manufacturers, who were already certified or who may become certified, towards

11 innovation in this form. Results show that the respondents rated themselves as more innovative

12 with respect to business systems innovation compared to product and process innovations.

13 Overall, innovation levels were low in the $\mathrm{BC}$ value-added wood products sector, a result which

14 was confirmed in the case of chain of custody certification.

\footnotetext{
${ }^{1}$ Postdoctoral Fellow, University of British Columbia, Faculty of Forestry, 2424 Main Mall, Vancouver, British Columbia V6T 1Z4. E-mail: haris.gilani@ubc.ca (corresponding author).

${ }^{2}$ Professor, Department of Wood Science, University of British Columbia, Faculty of Forestry, 2424 Main Mall, Vancouver, British Columbia V6T 1Z4. E-mail: rob.kozak@ubc.ca

${ }^{3}$ Professor and Dean, University of British Columbia, Faculty of Forestry, 2424 Main Mall, Vancouver, British Columbia V6T 1Z4. E-mail: john.innes@ubc.ca
} 


\section{$1 \quad$ Introduction}

2 Historically, the forest industry in British Columbia (BC), Canada, has been a production-

3 focused sector, largely mass producing and exporting primary forest product commodities, such

4 as lumber, plywood and pulp and paper (Schultz et al. 2013). However, after decades of industry

5 growth, the forest-based economy in $\mathrm{BC}$ has recently waned, and growth rates in the production

6 of these commodities have levelled off or declined (Edenhoffer and Hayter 2013). Overall, many

7 industry observers believe that the $\mathrm{BC}$ forest products industry faces significant challenges with

8 respect to maintaining its competitiveness and levels of employment (Schultz et al. 2013; Innes

$92009)$.

Given the current situation, enhancing innovation is increasingly seen as a path to competitive

11 advantage and improved financial performance. Due to the rise of manufacturing in developing

12 countries, notably China, there has been an escalation of interest among stakeholders in the

13 potential for innovation to counteract the loss of global competiveness and increase profitability

14 (Hansen 2010). However, contrary to common belief, the notion that innovation is a key to

15 competitiveness is not widely supported in the forest products industry literature (Knowles et al.

16 2008). The forest sector is perceived as being traditionally conservative and reluctant to adopt

17 changes, even when these can be shown to be beneficial (Innes 2009). Hansen et al. (2014)

18 describe forest sector companies as typically isolated, with limited knowledge transfer capacities,

19 a tendency to inadequately utilize market opportunities and a weak focus on innovation.

20 Most innovation research focusing on the forest products industry suggests that there are three

21 primary areas of innovation: product, process and business systems (Hovgaard and Hansen 2004;

22 Hansen et al. 2007). Product innovation refers to developing products in new ways that satisfy

23 customer needs, or create new, previously unrecognized needs. Process innovation refers to 
1 improved processes, such as improved efficiency in raw material utilization, computer-aided

2 manufacturing and customized machinery (Hovgaard and Hansen 2004). Business systems

3 innovation represents the myriad activities that a firm can use to improve business and marketing

4 management practices (Hovgaard and Hansen 2004). Consequently, innovativeness is defined as

5 the propensity of firms to create and (or) adopt new products, manufacturing processes and

6 business systems (Knowles et al. 2008). In other words, an innovative firm tends to be an early

7 adopter of new concepts, products and technologies; tends to develop, create and apply new

8 ideas, concepts and products; or some mix of the two (Hansen et al. 2014).

9 Most existing research points to a forest products industry that is focused on process innovation

10 (Hansen 2010), particularly as it relates to cutting the cost of production of a limited range of

11 commodity products (Innes 2009). For example, the twentieth century saw primary wood

12 processing (lumber production) increasing its wood utilization rate (by volume) from 25-30

13 percent of the $\log$ to over 50 percent of the $\log$ (Wagner and Hansen 2005). However, the

14 resultant product, dimension lumber, has remained largely unchanged over the past decades,

15 justifying the industry's reputation as a laggard with respect to product or business systems

16 innovation. That said, recent unique ways of addressing environmental issues, e.g. third-party

17 forest certification, have been regarded as a distinct form of business systems innovation

18 (Wagner and Hansen 2005).

19 A range of factors hindering innovation in the forest sector has been reported in previous

20 research. For instance, institutional and other barriers to innovation may sometimes explain the

21 relatively slow adoption of innovations in the forest sector (Rosenberg et al. 1990; Innes 2003).

22 Little space in new policy development for innovation means that many government forestry 23 departments are oftentimes risk-averse and unwilling to create policies that can promote 
1 innovation (Vosick et al. 2007). A similar pattern was evident at an industrial scale: larger

2 companies in the U.S. forest products industry are more likely to adopt process innovation, but

3 smaller companies may neutralize this competitive advantage by more likely adopting product

4 and business systems innovations (Wagner and Hansen 2005), suggesting that resources and

5 higher levels of networking increase the ability to be innovative (Crespell et al. 2006). Lack of

6 priority, lack of slack resources (time and money), low levels of knowledge, lean centralized

7 organizations, a traditional culture, and a commodity mentality are all cited as significant barriers

8 to innovation within forest products companies (Hansen 2006; Stendahl and Roos 2008).

9 While innovation-related research in the forest products industry has focused largely on the 10 primary wood products sector, secondary or value-added manufacturers appear better able to turn 11 innovativeness into improved financial performance (Valimaki et al. 2004; Crespell and Hansen 12 2008). However, insight into the innovation portfolio of the secondary wood products sector is 13 still scant. There is no universally accepted definition of value-added wood products, but most 14 industry observers agree on a general definition based on product groups. Value-added wood 15 products use solid wood as inputs for remanufacturing into semi-finished and finished products. 16 Examples include various types of panels, engineered composites, millwork, hardwood 17 components, as well as consumer products like doors, windows, furniture and cabinets (Vlosky 18 et al. 1998). Several value-added products, such as engineered wood products, represent a 19 relatively new category of products, providing an example of product innovation. Companies 20 developing these products have been able to open new markets not previously available to the 21 traditional forest products industry (Innes 2009). 
1 In this paper, we use the example of forest certification as an example of an innovation that

2 value-added wood producers can pursue. Forest certification is a mechanism that has as its

3 primary objective the improvement of forest management through marketing incentives (Upton

4 and Bass 1996). Forest certification aims at greater efficiency in forest resource use through an

5 expected increase in consumer demand for sustainably produced forest products (Cashore et al.

6 2004). It has also been variously defined as a market-based conservation initiative aimed at

7 reducing the impacts of poor or illegal logging (Leslie 2004), a nonstate market-driven

8 mechanism providing incentives to conform to procedures and standards in sustainable forest

9 management (Cashore et al. 2004), or a process of labeling wood that has been harvested from a

10 well-managed forest (Natural Resources Defense Council 2016), amongst others. The emergence

11 and interest in non-state market-driven forest certification programs can be traced to the

12 economic and political trends in the early 1990s, when market-oriented policy instruments

13 became increasingly important strategic tools both domestically and internationally (Cashore et

14 al. 2003).

15 There are normally two types of forest certification, namely forest management certification and

16 chain of custody certification (Elliot 2000). Forest management certification involves the

17 inspection of forest management on the ground against specific standards which usually include

18 ecological, economic and social elements, as well as a review of relevant documents such as

19 management plans and inventories. Chain of custody $(\mathrm{CoC})$ certification, on the other hand, is a

20 market-based tool that involves tracing round wood and processed timber products through the

$21 \mathrm{CoC}$ (or supply chain) from the forest through processing and distribution to the final purchaser.

22 The process of chain of custody certification provides assurance to customers in the marketplace

23 that certified wood products originate from sustainably managed forests. Situated in the middle 
1 of the forestry supply chain, value-added wood producers are ideally suited to adopt CoC as a

2 business innovation (Vidal et al. 2005).

3 The $\mathrm{BC}$ value-added wood products sector has the potential to be a champion of

4 environmentally-friendly or 'green' products and to create thousands of new jobs, hundreds of

5 millions of dollars in incremental manufacturing sales, new profits for entrepreneurs and higher

6 government revenue streams to pay for public services (Schultz et al. 2013). However, it has yet

7 to gain prominence as an industrial sector in $\mathrm{BC}$, despite the 'wood culture' that is in place

8 (Parfitt 2011). A possible explanation for this failure may be that value-added wood products

9 companies are unable or unwilling to take the risks that are inevitably associated with innovation

10 and may face a number of significant challenges related to innovation, including a fear of

11 change, ineffective management and poor communications (Crespell and Hansen 2008).

\section{Methodology}

13 The Tailored Design Method (Dillman 2000) was used to design and administer an online

14 survey. According to McIlhenney et al. (2013), there are 700 to 800 value-added wood producers

15 in British Columbia. Lists of companies were obtained primarily from the directory of secondary

16 manufacturing in $\mathrm{BC}$, as well as from other sources, such as the Log World directory and

17 membership lists of the BC Wood Specialties Group. Email addresses of companies were

18 obtained either from companies' websites or by telephoning them. Telephone conversations with

19 company representatives were conducted to ensure that the targeted audiences for this survey

20 were management representatives of the companies. The final list included 373 value-added

21 producers in British Columbia with valid email addresses. All of these 373 companies were

22 contacted via email and invited to participate in an online survey. Since this research was 
1 conducted through an online survey, only companies that had valid email addresses were invited

2 to participate in the survey. Companies that did not have email addresses or refused to provide

3 their email addresses were excluded from the study.

4 The initial email containing a survey link was sent to the 373 identified value-added wood 5 producers in British Columbia in October, 2013. The email explained the objectives of the 6 survey, the importance of participation by companies, and the overall value of the survey to the 7 sector. Non-respondents were sent follow-ups three times every two weeks after the initial 8 deadline. This was done as multiple contacts are more effective than using other techniques to 9 increase the response rate for surveys (Dillman 2000).

10 In this study, innovativeness was defined as the propensity of firms to create and (or) adopt new 11 products, manufacturing processes and business systems (Knowles et al. 2008), a categorization 12 that is supported by previous forestry industry research findings (Hovgaard and Hansen 2004; 13 Hansen et al. 2007). To measure innovativeness in the BC value-added wood products sector, an 14 indirect self-evaluation scale was designed to assess the propensity of value-added manufacturers 15 to innovate on these three dimensions. This scale was composed of nine items, each being 16 assessed using a five-point Likert scale (with 1 being "strongly disagree" and 5 being "strongly 17 agree"). Survey items that were considered to be indicators of product innovation included readiness to develop new products, readiness to take on a leading role in $R \& D$ for new products 19 and having a diversified product line. Items for process innovation included readiness to install new processing equipment, efficiency in raw material use and capitalizing on innovative

21 processes from other industries. Business systems innovation included factors such as readiness

22 in seeking new customers, willingness to bear marketing costs and the ability to train new 23 marketing managers. 
1 Means were calculated for each variable, i.e., type of innovativeness, with the assumption -

2 common in market studies - that the five points on the scale are equi-distant (interval scale). A

3 one-sample $t$-test was used to determine if the means for these scales were significantly different

4 from the midpoint of the scale (3), which indicates a neutral position regarding firm

5 innovativeness. Testing to determine if the values are significantly different from the scale

6 midpoint gives an indication that respondents have strong opinions (one way or the other)

7 regarding the innovativeness of their firms.

$8 K$-means cluster analysis was used to categorize responding companies based on their degrees of

9 innovativeness. Innovation-related questions on which cluster analysis was performed were

10 asked of certified and interested companies only (40 companies in total). The three variables

11 used to create clusters of companies included product innovation, process innovation and

12 business systems innovation. $K$-means cluster analysis is a useful technique used for

13 classification of objects without prior assumptions about the population (Punj and Stewart 1983).

14 The procedure identifies relatively homogeneous groups of cases based on selected

15 characteristics and is frequently used in marketing research when there is a need to group the

16 firms or consumers in homogenous groups in order to find comparable segments to test the

17 market (Ketchen and Shook 1998). The $K$-means clustering procedure was undertaken in this

18 analysis using SPSS 22.0 and solutions for two and three clusters were explored. However, only

19 the two cluster solution is reported here as it yielded meaningful results. Ten iterations were

20 required to minimize variability within and maximize variability between the two clusters.

21 Three variables were chosen for the analysis of the companies' characteristics in the two-cluster

22 solution. These variables included company size, proportion of sales in the international markets

23 and interest in $\mathrm{CoC}$ certification. We used the number of full-time employees as an indicator for 
1 company size. Previous research has shown that larger companies tend to be more innovative

2 than smaller companies (Rametsteiner and Weiss 2004). Therefore, it was assumed that the size

3 of the company could affect its propensity to adopt and (or) create innovation. Additionally,

4 companies that are export-oriented have been found to be more innovative (Wagner and Hansen

5 2005). According to UNECE (2013), markets for value-added wood products are more advanced

6 in the USA and Europe than in Canada. Therefore, a desire to increase the proportion of sales in

7 international markets, particularly in the USA and Europe, could be an indication of more

8 innovative companies. As the data representing the average sales volumes in the US and

9 European markets were given in percentages (between $0 \%$ and $100 \%$ ), they were normalized

10 using the arcsine transformation, i.e. $x^{\prime}=$ arcsine $\sqrt{ } x \%$. Finally, having an interest in CoC

11 certification is an example of a business systems innovation; many value-added wood products

12 companies are changing their corporate strategies by addressing environmental issues through

13 initiatives such as third-party environmental certification (Karna et al. 2002). Adoption and/or

14 interest in $\mathrm{CoC}$ certification can, therefore, be considered a direct indication of business systems

15 (market) innovation.

16 Independent samples $t$-tests $($ alpha $=0.05)$ were performed to test if there were any significant

17 differences in the two clusters between the number of full-time employees and the proportions of

18 products destined to export markets (the United States and Europe) using Levene's $F$-Test (for

19 homogeneity of variances) and Welch's $t$-test (with equal variances not assumed). A $Z$-test

20 (alpha $=0.05)$ was used to compare the proportions of certified companies between the two

21 clusters.

22 Finally, using Rogers' (2003) Diffusion of Innovations (DOI) theory, perceived attributes of an 23 innovation, including relative advantage, compatibility, complexity, trialability and 
1 observability, were measured in order to determine factors that inhibit or facilitate CoC

2 certification adoption (as an example of a business systems innovations). A five-point Likert-

3 type scale, with 1 being "strongly disagree" and 5 being "strongly agree", was applied to assess

4 these perceived attributes (that were treated as interval in nature). For each item in the Likert

5 scale, means were computed in order to position the relative importance of each item, and $95 \%$

6 percent confidence intervals were constructed. Mean values of each statement were tested

7 against a neutral value of 3 (at alpha $=0.05)$, which represents a neutral attitude for each

8 variable, in order to ascertain whether or not the perceived attributes of innovation were

$9 \quad$ significant.

10 The reliability or the internal consistency, of the scale items used in the survey were estimated by

11 using a reliability coefficient, Cronbach's alpha. An internal consistency analysis was performed

12 separately for each of the constructs of quality management. Typically, a reliability coefficient of

130.7 is considered to be acceptable; however, lower thresholds are also sometimes used in the

14 literature (Nunally 1978). Higher values of Cronbach's alpha indicate a higher degree of

15 reliability. The reliability values for most of the scales used in this study range from 0.6 to 0.8 ,

16 indicating that scales used was generally reliable.

17 Content validity is the degree to which elements of an assessment instrument are relevant to and 18 representative of the targeted construct for a particular assessment purpose (Haynes et al. 1995).

19 A measure has content validity if there is a general agreement among the subjects and 20 researchers that the instrument has measurement items that cover all aspects of the variable being 21 measured. In this study, the innovativeness questions were mainly based on previous studies 22 (Hovgaard and Hansen 2004; Hansen et al. 2007) who had selected the measurement items based 23 on an extensive literature review. Furthermore, the authors of this study reviewed the relevant 
1 literature on Rogers' Theory of Diffusion of Innovations to develop constructs to measure

2 perceived attributes of innovations and made adjustments to the instrument to ensure content

3 validity.

\section{$4 \quad 3 \quad$ Results}

\section{$5 \quad 3.1 \quad$ Non-response bias}

6 Of the 373 companies sampled, 123 companies completed the survey, resulting in a $33 \%$

7 response rate. In order to test for non-response bias, the data were divided into two groups

8 according to the completion dates of each response, as comparing early (initial) respondents to

9 respondents of follow-up mailings (later respondents) can be used to test for non-response bias

10 (Armstrong and Overton 1977). Responses from the first two email invitations were considered

11 early respondents and the respondents from last two email invitations were considered late

12 respondents. Data from the early respondents were combined and tested against the data from the

13 later respondents on three key variables: proportion of certified and non-certified companies,

14 average number of full-time employees and average percentage of sales volume within BC.

15 Two-tailed $t$-test and Z-tests were conducted to test the hypotheses that there were no significant

16 differences between the population parameters between early and late respondents with respect

17 to the average number of full-time employees, the average percentage of sales volume within $\mathrm{BC}$

18 and certification status (certified or not). Since the data representing the average percentage of

19 sales volume within $\mathrm{BC}$ were given in percentages between $0 \%$ and $100 \%$, an arcsin

20 transformation was conducted to normalize the data.

21 Table 1 summarizes the means and the proportions for each variable selected, as well as the $p$ -

22 values $($ alpha $=0.05)$ obtained by testing the differences between each set of means and 
1 proportions. Notably, no between-group mean differences were found between early and late

2 7 this approach. respondents. From this, it was concluded that non-response bias was not a major factor in this research. Although the non-response bias was not found to be statistically significant, there were some unavoidable limitations given the nature of the sampling in which only companies with a valid email address were targeted. Therefore, to generalize the results to the entire value-added wood products sector, the study should have also involved companies that were excluded using

To further test for non-response bias, an existing study based on a large survey conducted in 2006 (Stennes \& Wilson 2008) was used as a benchmark. This study reflected the entire population of the $\mathrm{BC}$ value-added wood producers. Three variables, including the firm size (measured by the average number of full-time employees and annual sales revenue), proportion of domestic sales and types of species utilized were used for comparative purposes (Table 2). These three variables were seen as a valid characterization of the $\mathrm{BC}$ value-added wood products sector, and have been used similarly in previous studies (DeLong et al. 2007; Kozak et al. 2003).

Although there were similarities between this study and the Stennes and Wilson (2008) study, some differences were also observed, indicating that there may be some degree of bias in our study. However, it could be argued that the observed differences merely reflect temporal differences, as other research has shown that the secondary wood products manufacturing sector in Canada is changing rapidly (DeLong et al. 2007). The sector began to decline in 2007 as a result of the 2008 recession, combined with the collapse of the North American housing market (Natural Resources Canada 2015). The recession heralded a period of slow global demand which significantly affected British Columbia's lumber output (Statistics Canada 2013). This, in turn, has changed the size, focus and nature of the value-added wood products sector and, from 1990 
1 to 2012, BC's share of the Canadian export market for almost all sub-sectors of the value-added

2 wood sector has declined (Schultz et al. 2013).

\section{$3 \quad 3.2 \quad$ Innovativeness in the $\mathrm{BC}$ value-added wood products sector}

4 The propensity of the $\mathrm{BC}$ value-added wood products sector to create and (or) adopt innovation

5 is shown in Table 3. Among the items measuring product innovations, the propensity to develop

6 new products and having diversified product lines, both with means of 3.8 , were found to be

7 significantly different from the midpoint (3). The respondents were less ready to take a leading

8 role in $\mathrm{R} \& \mathrm{D}$ for new products, having the lowest mean (3.1) among all items that measure

9 product innovations.

In terms of process innovations, the propensity for efficient raw material use (mean $=3.9)$ and

11 the propensity to install new processing equipment (mean $=3.3$ ) were significantly different

12 from the midpoint. Value-added producers were not taking advantage of innovative processes

13 from other leading industries, having the lowest mean (mean $=3.2$ ) among all items measuring

14 process innovations.

15 Business systems innovations were rated marginally higher (overall mean of 3.6) than product or

16 process innovations (both with overall means of 3.5). Of the business systems innovations, the

17 propensity to look for new customers had the highest mean value (mean $=4.1$ ) and was

18 statistically different from the midpoint. The organization's readiness to bear the cost of

19 marketing for products promotion was also significantly different from the midpoint, with a

20 mean of 3.5 . 


\subsection{Two-cluster solution}

2 A K-means cluster analysis, based on the propensity to innovate statements shown in Table 3,

3 was conducted to categorize groups of value-added companies according to their degree of

4 innovativeness. As the cluster analysis was performed on companies that were currently certified

5 or were interested in certification $(n=40)$, the two-cluster solution resulted in equal sample sizes

6 of 20 members in each cluster. The final cluster centres are shown in Table 4 with the mean of

7 Cluster 1 being 3.8 and the mean of Cluster 2 being 3.2, indicating that Cluster 2 has more of a

8 tendency towards neutrality where innovation is concerned.

9 In order to establish profiles of the clusters, the characteristics of each cluster were aggregated.

10 Table 5 shows the variables that were used to study the distinct characteristics of each cluster,

11 including average numbers of employees, average percentages of export volumes (USA and

12 Europe) and proportions of certified and non-certified, but interested, companies.

13 The mean number of employees in Cluster 1 was 42.1 versus 91.8 in Cluster 2. However, there

14 was no significant difference between the numbers of full time employee means in the two

15 clusters. Similarly, the mean sales percentages to USA and European markets were not

16 significantly different between the two clusters, nor were the proportions of certified companies.

17 Even though no significant differences between the two clusters were uncovered, some distinct

18 trends were noted. Cluster 1 was comprised primarily of medium-sized companies, with almost

19 one-quarter $(24.4 \%)$ of their sales volume being exported to the United States. These companies

20 showed a generally neutral view towards innovation with $80.0 \%$ of the companies being

21 certified. Cluster 2 was comprised primarily of larger companies with higher proportions of

22 export volumes destined for the United States (24.4\% vs 37.3\%). These companies also showed 
1 a generally neutral view towards innovation, but the proportion of certified companies was lower

2 than in Cluster 1, at 70.0\%.

\section{$3 \quad$ 3.3 Attitudes of certified and interested companies}

4 Of the 121 total respondents, $41.0 \%$ were certified, while another $13.0 \%$ of respondents were not

5 certified, but were interested in becoming certified within five years. The remaining $46.0 \%$ were not certified and had no interest in becoming certified. The certified $(n=49)$ and interested

7 companies $(n=15)$ were further investigated to determine their attitudes towards chain of 8 custody certification.

9 With aggregated ratings significantly higher than neutral, certified companies (CCs) believed that certification helped to improve their corporate image $($ mean $=3.9)$, was compatible with company values (mean $=3.8)$ and helped in meeting requirements of other policy instruments such as LEED ${ }^{4}$, the Lacey Act $^{5}$ and FLEGT $^{6}$ (mean = 3.5) (Figure 1). A majority of certified companies (CCs) also believed that certification helps access new markets (mean $=3.4)$ and that the requirements of certification standards fit well with their existing processes and procedures $($ mean $=3.3)$. However, attitudes regarding the likelihood of enhanced effectiveness of the production processes $($ mean $=2.2)$ were significantly lower than neutral. Other variables under

17 study showed no significant differences from neutral.

\footnotetext{
${ }^{4}$ The Leadership in Energy and Environmental Design (LEED) program, administered by the Green Building Council is the leading third-party certifier of sustainable construction projects in North America. It was initiated in 1998 as a voluntary program for designing sustainable, highperformance buildings (Germain et al. 2010).

${ }^{5}$ The Lacey Act aims to build markets for verifiably legal products by banning the import and sale of illegally-sourced timber and other plant products in the United States (U.S. Fish \& Wildlife Service 2016).

${ }^{6}$ Forest Law Enforcement, Governance and Trade (FLEGT) is the European Union response to illegal logging, which aims to reduce illegal logging by strengthening sustainable and legal forest management, improving governance and promoting trade in legally produced timber (EU FLEGT 2016).
} 
1 out of the 18 statements, the mean for these companies indicated strong agreement or agreement

2 (a rating above 3). NCIC respondents believed CoC certification can be adapted or modified to

3 suit the production process within their organizations (mean $=4.4)$. NCICs also viewed CoC

4 certification as a pathway to meeting requirements of LEED, the Lacey Act and FLEGT (mean $=$

5 4.4), indicating that they perceive CoC certification to be compatible with other market-driven

6 instruments. Unlike certified companies, NCICs believed adopting CoC certification will lead to

7 increased price premiums on certified products $($ mean $=4.3)$, indicating that many interested

8 companies perceived the relative advantage of $\mathrm{CoC}$ certification positively. NCICs also agreed

9 that $\mathrm{CoC}$ certification helps access new markets (mean $=3.9)$ and that it improves corporate

10 image $($ mean $=4.0)$ and is compatible with company values (mean $=4.1)$. In terms of the impact

11 of $\mathrm{CoC}$ certification on the effectiveness of the production process, NCIC respondents held

12 similarly negative views as CCs $($ mean $=2.8)$.

\section{Discussion}

14 The results of this study indicate that despite significant differences compared to a neutral scale

15 value, mean values for all types of innovativeness tended to cluster closer to the scale midpoint

16 (3) than to the upper end of the scale (5), with the exception of the propensity to look for new

17 customers. This indicates that, overall, the value-added wood manufacturers in this study, while

18 embracing innovation to a certain extent, do not have particularly strong positive (or negative)

19 views on the innovativeness of their firms. The cluster analysis shows a distinct homogeneity

20 within the $\mathrm{BC}$ value-added wood products sector when it comes to innovativeness. This implies

21 that the value-added wood products sector follows the trend of primary manufacturers in terms of

22 innovativeness, a result that was borne out in a study conducted by Knowles et al. (2008), which 
1 assessed the innovativeness of softwood sawmills in the USA and Canada and found that

2 respondents did not have strong positive views about the innovativeness of their mills.

3 That the respondents in this study had very positive views regarding only one item related to

4 business systems innovativeness, the propensity to look for new customers, is encouraging given

5 that the industry has traditionally focused on existing customers versus new customers, and

6 consequently, incremental versus radical innovations (Hansen 2006). A customer focus suggests

7 not merely reacting to existing customer demands, but proactively seeking to meet the needs of

8 new customers and the changing needs of existing customers (Leavengood and Anderson 2014).

9 According to Hansen (2006), firms rely heavily on customers for innovative ideas. Customers

10 can be significant drivers of innovation and successful new product development (NPD) by

11 maintaining close connections with manufacturers during product development. Experts suggest

12 that the wood products industry needs to shift to a market-oriented culture in order to improve

13 innovation performance and a major component of such a shift includes how firms interact with

14 their customers and competitors (Leavengood and Bull 2014). Many value-added wood product

15 manufacturers in $\mathrm{BC}$ lack in-house capacity and resources to design and develop new products

16 (Schultz et al. 2013). Unfortunately, there is insufficient recent empirical data in BC to suggest

17 which new products have the greatest growth potential, which markets should be pursued and

18 which products best match with its current resource base. These knowledge gaps need to be 19 filled.

20 This survey found that the major focus of innovations in the value-added industry was for

21 business systems. These results are consistent with Wagner and Hansen (2005), who found that

22 smaller companies are more likely to adopt business systems innovations, whereas larger 23 companies outperform smaller companies in process innovations since they have greater access 
1 to capital for these purposes. In another study of 587 U.S. firms, Cohen and Klepper (1996)

2 found that large firms have a greater incentive to engage in R\&D activities for which they have 3 'appropriability advantages' compared to smaller firms. These advantages are strong when

4 knowledge is less tradeable, in 'disembodied forms', as in the case of process innovations given

5 effective intellectual property protection. Our survey results also indicate that the respondents

6 were least innovative with respect to taking a leading role in $R \& D$ for new products. $R \& D$ and

7 innovation are inextricably connected (Leavengood and Bull 2014). Capacity to innovate is a

8 central factor of success for value-added wood products sectors around the world, and

9 governments generally play a major role through direct investment in research and education

10 (Schultz et al. 2013). Despite the presence of world class universities and research institutions in

11 BC focusing on wood products, the capacity to undertake research related to the technology

12 interests and needs of the value-added wood sector wood products is significantly challenged

13 (Schultz et al. 2013). The sector is composed primarily of small and medium sized enterprises,

14 and management capacity is routinely focused on their normal business operations, with a lack of

15 organizational slack to focus on short- and long-term research interests. Hence, individual

16 engagement between producers and the research infrastructure is particularly challenging in $\mathrm{BC}$

17 (Schultz et al. 2013).

18 In this study, the two-cluster solution showed that, on average, both clusters had generally 19 neutral views on all three measures of product, process and business systems innovations. This 20 indicates that, regardless of the company size, adoption and creation of innovations in the $\mathrm{BC}$ 21 value-added wood products sector is largely slow and homogenous. Given that the majority of 22 businesses in this sector are small- and medium-sized enterprises (SMEs) (DeLong et al. 2007), 23 enterprises oftentimes lack the capacity to invest in innovation-related activities. The 
1 Organization for Economic Co-operation and Development (OECD 2010) estimates that, on

2 average, firms tend to spend $1-2 \%$ of turnover on various innovation-related activities, but this

3 share exceeds 5\% for large firms in some countries. Paradoxically, Canada is a leading country,

4 spending more than $5 \%$ of turnover on innovation, both in the categories of SMEs and large

5 manufacturing firms (OECD 2010). A more thorough understanding of what proportion of the

6 annual turnover is spent on innovation by the $\mathrm{BC}$ value-added wood products manufacturers and

7 what barriers to innovation exist for these SMEs are research questions that should be addressed

8 in future studies. These questions are especially germane as innovation is central to the success

9 of the value-added wood products sector in light of increasingly fickle markets and intense competition from low-cost producers in developing regions.

11 The two-cluster solution also failed to uncover significant difference between the clusters with

12 respect to the proportion of certified companies. While the adoption of chain of custody

13 certification has grown in the past few years in the BC value-added sector (Gilani 2015), our

14 survey indicated that a large number of companies were not interested in pursuing certification.

15 The example of certification - as a business innovation - illustrates that, despite all the perceived

16 benefits of certification, chain of custody certification is characterized by a slow rate of adoption,

17 hence corroborating the overall view that innovation progresses slowly in the sector. This result

18 is surprising given that many companies in the forest sector are shifting to the use of raw

19 materials from well-managed forests, addressing environmental concerns and using certification

20 processes to demonstrate their sustainability credentials due to changing market requirements

21 and globalization (Leavengood and Bull 2014). In fact, over the past few decades, environmental

22 certification and a corporate focus on exports are two of the more successful initiatives that have

23 been noted with respect to business systems innovations in the forest sector (Wagner and Hansen 
1 2006). This implies that, while certified forest companies are investing in chain of custody

2 certification as a tool to access new markets, such as the United States and Europe where more

3 stringent measures to control illegal wood are in place, the value-added wood products sector in

$4 \mathrm{BC}$ is lagging in this regard. Given that certification is generally regarded as a pathway for

5 addressing legality requirements (UNECE 2012), initiatives such as the Lacey Act amendments

6 and FLEGT may help to catalyze interest in certification among BC value-added wood producers

7 should emergent markets dictate proof of legality.

8 This survey indicated a difference in attitudes towards $\mathrm{CoC}$ certification between two groups of 9 respondents, certified companies (CCs) and non-certified but interested companies (NCICs).

10 This may be because NCICs had not yet adopted the CoC certification, so their responses reflect

11 their expectations, whereas CCs responses were more indicative of their actual experiences

12 (Figure 1). From the survey results, it can be generalized that NCICs were relatively optimistic

13 about the economic benefits of $\mathrm{CoC}$ certification, whereas the actual experience of CCs

14 demonstrates that while certification improves the corporate image, tangible benefits such as

15 price premiums have not yet been achieved.

16 According to this study, CCs considered a company's corporate image and meeting the

17 regulatory requirements of LEED certification as the two most important determining factors for

18 adopting $\mathrm{CoC}$ certification, a result that is consistent with the findings of previous studies (Perera

19 et al. 2008; Chen et al. 2011). In this context, CoC certification appears to imply that a company

20 is managing its business well and is showing ethical and environmental responsibility. The fact

21 that a company has been awarded the $\mathrm{CoC}$ certification by an independent third-party enhances

22 its perceived reliability and credibility. 
1 The NCICs in this study were generally optimistic about certified wood markets, believing that

2 certification had the potential to command price premiums and would help to meet the regulatory

3 requirements for LEED certification. Interestingly, current Canadian procurement requirements

4 involve a commitment from the Public Works and Government Service Canada to achieve LEED

5 Gold standard certification for all new public buildings (Government of Canada 2010). Such

6 policies can create momentum and catalyze further adoption of forest certification (beyond

7 merely $\mathrm{CoC}$ ) because wood products certified by an FSC standard also contribute, in a very

8 minor way, to certification under the LEED standard (Tikina et al. 2012).

9 Seeking market benefits and compatibility with companies' values (such as access to new markets) also appear to be motivating factors for CCs and NCICs to adopt CoC certification.

11 Both groups were also of the view that $\mathrm{CoC}$ certification does not enhance the efficiency of the

12 production process. The most likely explanation for this is that maintaining certification requires

13 an enormous amount of paperwork and tracking and (or) the allocation of physical space for 14 separating CoC-certified products from other products (Chen et al. 2011).

15 NCICs did not perceive CoC certification to be a complex process, which is not surprising given 16 that they had not actually adopted certification and were not, therefore, exposed to the 17 particularities of the $\mathrm{CoC}$ process and standards. Conversely, even though CCs had a general 18 belief that the $\mathrm{CoC}$ standards are relevant to the value-added wood products industry, they 19 perceived $\mathrm{CoC}$ certification to be a relatively complex process. CCs indicated difficulties in 20 factors such as understanding $\mathrm{CoC}$ standards, choosing the right certification scheme, and a lack 21 of clarity surrounding $\mathrm{CoC}$ standards. Furthermore, $\mathrm{CoC}$ certification requires significant 22 resources to train staff, which adds increased burden to these manufacturers. 
1 Finally, for value-added wood producers (in British Columbian and elsewhere) interested in

2 adopting $\mathrm{CoC}$ certification, it should be noted that the diversity of ecolabels, reflecting the

3 multitude of certification schemes that proliferate the market, can be confusing to customers and

4 weaken the credibility of all labels (Fisher et al. 2005). Coordination and competition in the field

5 of certification has been cited as a major challenge to the legitimacy of certification schemes

6 (Marx 2011). Different organizations that essentially have the same social and environmental

7 goals are currently operating alongside one another. Competition between the certifiers can lead

8 to a 'race to the bottom' in an effort to increase market shares, thereby compromising

9 enforcement mechanisms (Marx 2014). However, initiatives have been developed to achieve

10 greater cooperation among certification schemes (Fischer et al. 2005). For example, the

11 Programme for the Endorsement of Forest Certification (PEFC), which is an umbrella

12 organization, has developed a common standard and endorses national forest certification

13 programs that meet its requirements.

\section{Conclusions}

15 This paper aimed to provide insights into the state of innovation in the British Columbia value-

16 added wood products sector. Innovation has been very slow in this sector, and largely restricted

17 to business systems innovation. While very few of the items measuring innovativeness were

18 rated highly, our results confirm the importance of business systems innovation relative to

19 product and process innovation. The measures of innovativeness that were rated more highly

20 revolved around a propensity to look for new customers (business systems innovation),

21 efficiencies in raw material use (process innovation) and diversified product lines (product

22 innovation). 
1 Chain of custody certification provides an interesting potential business innovation in the BC

2 value-added wood products sector, and some companies currently use it as a marketing tool.

3 However, the sector has been slow to adopt this innovation, again supporting the view that many

4 value-added wood producers have been slow to adopt innovative practices. Identification of the

5 main driving forces revealed some dissimilarities in the motivations and attitudes toward CoC

6 certification between the certified companies and non-certified but interested companies (CCs

7 and NCICs, respectively). Among the NCICs, initiation of the $\mathrm{CoC}$ process is motivated by

8 external factors, mainly linked to the price premiums and participation in LEED projects. CCs,

9 on the other hand, appear to be affected by both internal and external factors, in particular,

10 internal corporate policies that view certification as being compatible with their companies'

11 values and corporate images, as well as the need to meet external market demand conditions,

12 such LEED requirements. CCs do not consider price premiums to be an added benefit in the

13 adoption of $\mathrm{CoC}$ certification and find the process difficult to implement due to its complexity.

14 Nevertheless, both groups of respondents were of the view that $\mathrm{CoC}$ certification is compatible

15 with their company's values.

16 The findings of this research suggest that companies within the $\mathrm{BC}$ value-added wood products

17 could refocus their innovation efforts on product and process innovation as they may benefit

18 from a more balanced portfolio approach to innovation and a more structured approach to

19 business systems innovation. The increasing importance of environmental issues, the increasing

20 competition from low-cost manufacturers in developing countries, the evolution of entirely new

21 products and many other changes could result in a very different sector to what exists today. To

22 cope with these changes and to remain globally competitive, actors in BC's value-added wood 
1 products sector should consider the adoption of genuine innovation strategies as a prerequisite 2 for their continued success. 


\section{$6 \quad$ References}

Armstrong, J.S., and Overton, T.S. 1977. Estimating nonresponse bias in mail surveys. Journal of Marketing Research 14 (3): 396-402.

Cashore, B., Auld, G., and Newsom, D. 2003. Forest certification (eco-labeling) programs and their policy-making authority: explaining divergence among North American and European case studies. Forest Policy and Economics, 5(3), 225-247.

Cashore B., Auld G., Newsom D. 2004. Governing through markets: Forest certification and the emergence of non-state authority. Yale University Press, New Haven, CT. 327 p

Chen, J., Tikina, A., Kozak, R., Innes, J.L., Duinker, P., and Larson, B. 2011. The efficacy of forest certification: Perceptions of Canadian forest products retailers. The Forestry Chronicle, 87(5), 636-643.

Crespell, P. and Hansen, E. 2008. Managing for innovation: insights into a successful company. For. Prod. J. 2008, 58, 6-17.

Crespell P., Knowles, C., and Hansen, E. 2006. Innovativeness in the North American softwood sawmilling industry. Forest Sci. 52:568-578.

Cohen, W.M. and Klepper, S. 1996. Firm size and the nature of innovation within industries: the case of process and product R\&D. The Review of Economics and Statistics 78(2): 232-243.

DeLong, D.L., Kozak, R., and Cohen, D. 2007. Overview of the Canadian value-added wood products sector and the competitive factors that contribute to its success. Canadian Journal of Forest Research 37(11):2211-2226.

Dillman, D.A. 2000. Mail and internet surveys: The tailored design method. 2nd ed. John Wiley, New York. 464 pp.

Edenhoffer, K. and Hayter, R. 2013. Restructuring on a vertiginous plateau: the evolutionary trajectories of British Columbia's forest industries 1980-2010.Geoforum, 44 (1), 139-51.

Elliott, C. 2000. Forest certification: a policy perspective. Cifor.

EU FLEGT [Online]. What is FLEGT? Available from http://www.euflegt.efi.int/about-flegt [accessed on March 16, 2016].

Fischer, C., Aguilar, F., Jawahar, P., and Sedjo, R. 2005. Forest certification: Toward common standards? Discussion paper 05-10 for the Foreign Investment Advisory Service of the World Bank Group. 
Germain, R. H., \& Penfield, P. C. 2010. The potential certified wood supply chain bottleneck and its impact on Leadership in Energy and environmental Design construction projects in New York State. Forest Products Journal,60(2), 114.

Gilani, H. 2015. Chain of custody certification adoption, innovation and change management in the British Columbia value-added wood products sector. PhD Thesis. University of British Columbia, Vancouver.

Government of Canada [online]. Planning for a sustainable future: A federal sustainable development strategy for Canada. Government of Canada, Sustainable Development Office, Environment Canada, Ottawa. Available from http://dsppsd.pwgsc.gc.ca/collections/collection_2010/ec/En4-136-2010-eng.pdf [accessed on February $10,2015]$.

Hansen, E. 2010. The role of innovation in the forest products industry. Journal of Forestry 108 (7):348-353.

Hansen, E. 2006. The state of innovation and new product development in the North American lumber and panel industry. Wood and Fiber Science 38 (2):325-333.

Hansen, E., Nybakk, E., and Panwar, R. 2014. Innovation insights from North American Forest Sector Research: A Literature Review. Forests, 5(6), 1341-1355.

Hansen, E., Juslin, H., and Knowles, C. 2007. Innovativeness in the global forest products industry: exploring new insights. Canadian journal of forest research, 37(8), 1324-1335.

Haynes, S. N., Richard, D., \& Kubany, E. S. (1995). Content validity in psychological assessment: A functional approach to concepts and methods.Psychological assessment, 7(3), 238.

Hovgaard, A. and Hansen, E. 2004. Innovativeness in the forest products industry. Forest Products Journal, 54(1), 26-33.

Innes, J.L. 2009. The promotion of 'innovation' in forestry: a role for government or others?, Journal of Integrative Environmental Sciences, 6:3, 201-215.

Innes, J.L. 2003. The incorporation of research into attempts to improve forest policy in British Columbia. Forest Pol Econ. 5:349-359.

Innes, J.L., and Hickey, G.M. 2005. Certification of forest management and wood products. Forestry and environmental change: socioeconomic and political dimensions. Report No. 5 of the IUFRO Task Force on environmental change, 143-167.

Karna, J. Hansen, E. and Juslin, H. 2002. Environmental activity and forest certification in marketing of forest products - A case study in Europe. Silva Fennica 37 (2).

Ketchen, D. and Shook, C.L. 1996. The application of cluster analysis in strategic management research: an analysis and critique. Strategic Management Journal 17(6): 441-458. 
Kozak, R.A., Maness, T. and Caldecott, T. 2003. Solid wood supply impediments for secondary wood producers in British Columbia. The Forestry Chronicle 79(6):1107-1120.

Knowles, C., Hansen, E., and Shook, S. 2008. Assessing innovativeness in the North American softwood sawmilling industry using three methods. Canadian Journal of Forest Research 38 (2):363-375.

Leavengood, S., and Bull, L. 2014. Innovation in the global forest sector. The 21 st century forest sector: Prospects and pathways. CRC Press, Boca Raton, FL, 377-404.

Leslie AD. 2004. The impacts and mechanisms of certification. Int. For. Rev. 6: 30-39

Marx, A. and Wouters, J. 2014. Competition and cooperation in the market of voluntary sustainability standards. Available at SSRN 2431191.

Marx, A. 2011. Global governance and the certification revolution: types, trends and challenges. Handbook on the Politics of Regulation, D. Levi-Faur, Editor.

McIlhenney, K. and Hayter, R. 2013. Sustaining jobs and environment? The value-added wood industry in Metro Vancouver, British Columbia. Local Environment: The International Journal of Justice and Sustainability, DOI: 10.1080/13549839.2013.854755

Natural Resources Defense Council. 2016. Good Wood: How Forest Certification Helps the Environment [online]. Available from http://www.nrdc.org/land/forests/qcert.asp [accessed on February 20, 2016].

Natural Resources Canada. 2015. Secondary manufacturing of forest products [online]. Available from http://www.nrcan.gc.ca/forests/report/industry-change/16542 [accessed on March $\left.31^{\text {st }}, 2015\right]$.

Nunnaly, J. (1978). Psychometric theory. New York: McGraw-Hill.

OECD. 2010. Measuring Innovation: A new perspective [online]. Available from http://www.oecd.org/site/innovationstrategy/45188199.pdf [accessed on March 31, 2015].

Parfitt, B. 2011. Making the case for a carbon focus and green jobs in BC's forest industry. Vancouver, BC: Hands on Publications.

Perera, P., Vlosky, R. P., Dunn, M. A., \& Hughes, G. 2008. US home-center retailer attitudes, perceptions and behaviors regarding forest certification. Forest Products Journal, 58(3), 21.

Punj. F. and D.W. Stewart. 1983. Cluster analysis in marketing research: review and suggestions for application. Journal of Marketing Research. 29(5):131-148.

Rametsteiner, E. and Weiss G. 2004. Innovation and entrepreneurship in forestry in central Europe. Paper presented at: Sustain life - secure survival II conference, 22-25 September 2004, Prague, Czech Republic [online]. 
Available from http://www.boku.ac.at/innoforce/publications/I\&E_ForestryCE_Prag04.pdf [accessed on July 2, 2014].

Rosenberg, N., Ince, P., Skog, K., and Plantinga, A. 1990. Understanding the adoption of new technology in the forest products industry. Forest Products J. 40(10):15-22.

Schultz, R. Kozak, R. A., Merkel, G. Sunderman, R., and Thrower, J. 2013. Growing the BC interior value-added wood sector. Summary report. Prepared for the Southern Interior Beetle Action Coalition.

Statistics Canada. 2013. The Great U.S. Recession and Canadian Forest Products [online]. Available from http://www.statcan.gc.ca/pub/11-626-x/11-626-x2013028-eng.pdf [accessed on April 1, 2015].

Stendahl, M. and Roos, A. 2008. Antecedents and barriers to product innovation-a comparison between innovating and non-innovating strategic business units in the wood industry. Silva Fennica, 42(4), 659-681.

Stennes, B. and Wilson, B. 2008. Secondary manufacturing of solid wood products in British Columbia, 2006: structure, economic contribution and changes since 1990. Pacific Forestry Centre.

Tikina, A. V., Kozak, R. A., Innes, J. L., Duinker, P. N., \& Larson, B. C. 2012. Forest certification in Canada: An exploratory study of perceptions of provincial and territorial government employees. The Forestry Chronicle,88(1), 40-48.

United Nations Economic Commission for Europe (UNECE). 2013. Forest products annual market review. 2012-2013. United Nations, Geneva, Switzerland.

United Nations Economic Commission for Europe (UNECE). 2012. Forest products annual market review. 2011-2012. United Nations, Geneva, Switzerland.

U.S. Fish \& Wildlife Service [Online]. Lacey Act. Available from http://www.fws.gov/international/laws-treaties-agreements/us-conservation-laws/lacey-act.html [accessed on March 16, 2016].

Välimäki, H., Niskanen, A., Tervonen, K., and Laurila, I. 2004. Indicators of innovativeness and enterprise competitiveness in the wood products industry in Finland. Scandinavian Journal of Forest Research, 19(sup5), 90-96.

Vidal, N., Kozak, R., \& Cohen, D. 2005. Chain of custody certification: an assessment of the North American solid wood sector. Forest Policy and Economics, 7(3), 345-355.

Upton, C. and Bass, S. 1996. The forest certification handbook. St. Lucie Press, Florida, USA.

Vlosky, R. and Ozzane, L. 1998. Environmental certification of wood products: The U.S. manufacturer's perspective. Forest Prod. J. 48(9):21-26. 
Vosick, D. Ostergren D.M., Murfitt, L. 2007. Old-growth policy. Ecol Soc. 12(2). art. 19.

Wagner, E. and Hansen, E. 2005. Innovation in large versus small companies: insights from the U.S. wood products industry. Manage Decision. 43(6):837-850. 
Table 1: Variables tested for non-response bias (early respondents vs. late respondents)

\begin{tabular}{cccc}
\hline & $\begin{array}{l}\text { Early respondents } \\
(\mathrm{n}=56)\end{array}$ & $\begin{array}{l}\text { Late respondents } \\
(\mathrm{n}=67)\end{array}$ & $p$-value \\
\hline Certification Status & & & \\
Certified & $27.9 \%$ & $57.5 \%$ & 0.25 \\
$\quad$ Non-certified & $49.0 \%$ & $50.0 \%$ & 0.91 \\
Average number of full-time employees & 39.7 & 53.7 & 0.47 \\
Average percentage of sales volume within BC & $55.2 \%$ & $36.0 \%$ & 0.93 \\
\end{tabular}

Table 2: Comparison of key variables in this study with Stennes \& Wilson (2008)

\begin{tabular}{|l|l|l|l|}
\hline Variable & Current research & Stennes \& Wilson (2008) \\
\hline \multirow{2}{*}{ Firm size } & Mean employment & 38.3 & 25.0 \\
\cline { 2 - 4 } & Annual sales revenue & $28.7 \% *$ & $33.0 \%$ \\
\hline Sales within BC & $95 \%$ & $97.0 \%$ \\
\hline Species consumed & Douglas-fir & $21.5 \%$ & $55.0 \%$ \\
\cline { 2 - 4 } & Western red cedar & $23.2 \%$ & $53.0 \%$ \\
\hline
\end{tabular}

* Percentage of companies with upto $\$ 1$ million sales category

Table 3: Results of propensity to create and (or) adopt measures of innovativeness in the BC value-added wood products sector

\begin{tabular}{|c|c|c|c|c|c|}
\hline Variable & Measurement & $\mathbf{N}$ & Mean & $\begin{array}{c}\text { Std. Error } \\
\text { Mean }\end{array}$ & $\begin{array}{c}\text { Sig. } \\
\text { (2- tailed) }\end{array}$ \\
\hline Product Innovations & $\begin{array}{l}\text { Our company is always seeking ways to develop new } \\
\text { products* } \\
\text { Our company takes leading role in R\&D for new } \\
\text { products } \\
\text { Our company has a diversified product line* } \\
\end{array}$ & $\begin{array}{l}40 \\
40 \\
40 \\
\end{array}$ & $\begin{array}{l}3.1 \\
3.8 \\
\end{array}$ & $\begin{array}{l}.12 \\
.13 \\
\end{array}$ & $\begin{array}{l}.44 \\
.00 \\
\end{array}$ \\
\hline Process Innovations & $\begin{array}{l}\text { Our company is always ready to install new processing } \\
\text { equipment* } \\
\text { Our company is very efficient in raw material use* } \\
\text { Our company takes advantage of innovative processes } \\
\text { from other leading industries }\end{array}$ & $\begin{array}{l}40 \\
40 \\
40\end{array}$ & $\begin{array}{l}3.3 \\
3.9 \\
3.2\end{array}$ & $\begin{array}{l}.13 \\
.10 \\
.12\end{array}$ & $\begin{array}{l}.00 \\
.00 \\
.07\end{array}$ \\
\hline Business Systems Innovations & $\begin{array}{l}\text { Our company is ready to look for new customers* } \\
\text { Our company is ready to bear the cost of marketing for } \\
\text { products promotion* } \\
\text { Our company is ready to train new marketing managers }\end{array}$ & $\begin{array}{l}40 \\
40 \\
40\end{array}$ & $\begin{array}{l}4.1 \\
3.5 \\
3.1\end{array}$ & $\begin{array}{l}.10 \\
.11 \\
.118\end{array}$ & $\begin{array}{l}.00 \\
.00 \\
.14\end{array}$ \\
\hline
\end{tabular}

* Denotes significantly different from midpoint of scale (3) at alpha $=0.05$

$(1=$ strongly disagree; 2 = disagree; $3=$ neutral; 4 = agree; $5=$ strongly agree $)$ 
Table 4: Final cluster centers

\begin{tabular}{|c|c|c|}
\hline & \multicolumn{2}{|c|}{ Cluster } \\
\hline & 1 & 2 \\
\hline Our company is always seeking ways to develop new products & 4 & 3 \\
\hline $\begin{array}{l}\text { Our company takes leading role in research } \& \text { development for } \\
\text { new products }\end{array}$ & 3 & 3 \\
\hline Our company has a diversified product line & 4 & 3 \\
\hline Our company is always ready to install new processing equipment & 4 & 3 \\
\hline Our company is very efficient in raw material use & 4 & 4 \\
\hline $\begin{array}{l}\text { Our company takes advantage of innovative processes from other } \\
\text { leading }\end{array}$ & 4 & 3 \\
\hline Our company is ready to look for new customers & 4 & 4 \\
\hline $\begin{array}{l}\text { Our company is ready to bear the cost of marketing for products } \\
\text { promotion }\end{array}$ & 4 & 3 \\
\hline Our company is ready to train new marketing managers & 4 & 3 \\
\hline Cluster Centre Means & 3.8 & 3.2 \\
\hline
\end{tabular}

( 1 = strongly disagree; 2 = disagree; 3 = neutral; 4 = agree; 5 = strongly agree $)$

Table 5: Characteristics of the two clusters

\begin{tabular}{|l|l|l|l|}
\hline \multicolumn{2}{|l|}{} & $\begin{array}{l}\text { Cluster 1 } \\
\mathrm{n}=20\end{array}$ & $\begin{array}{l}\text { Cluster 2 } \\
\mathrm{n}=20\end{array}$ \\
\hline Number of employees & 42.1 & 91.8 \\
\hline \multirow{2}{*}{$\begin{array}{l}\text { Export sales } \\
\text { destination }\end{array}$} & United States & $24.5 \%$ & $37.3 \%$ \\
\cline { 2 - 4 } & Europe & $18.3 \%$ & $12.5 \%$ \\
\hline Certification status & Certified & $80.0 \%$ & $70.0 \%$ \\
\cline { 2 - 4 } & Non certified, but interested & $20.0 \%$ & $30.0 \%$ \\
\hline Cluster Centre Means & $\mathbf{3 . 8}$ & $\mathbf{3 . 2}$ \\
\hline
\end{tabular}

( 1 = strongly disagree; 2 = disagree; 3 = neutral; 4 = agree; 5 = strongly agree $)$ 


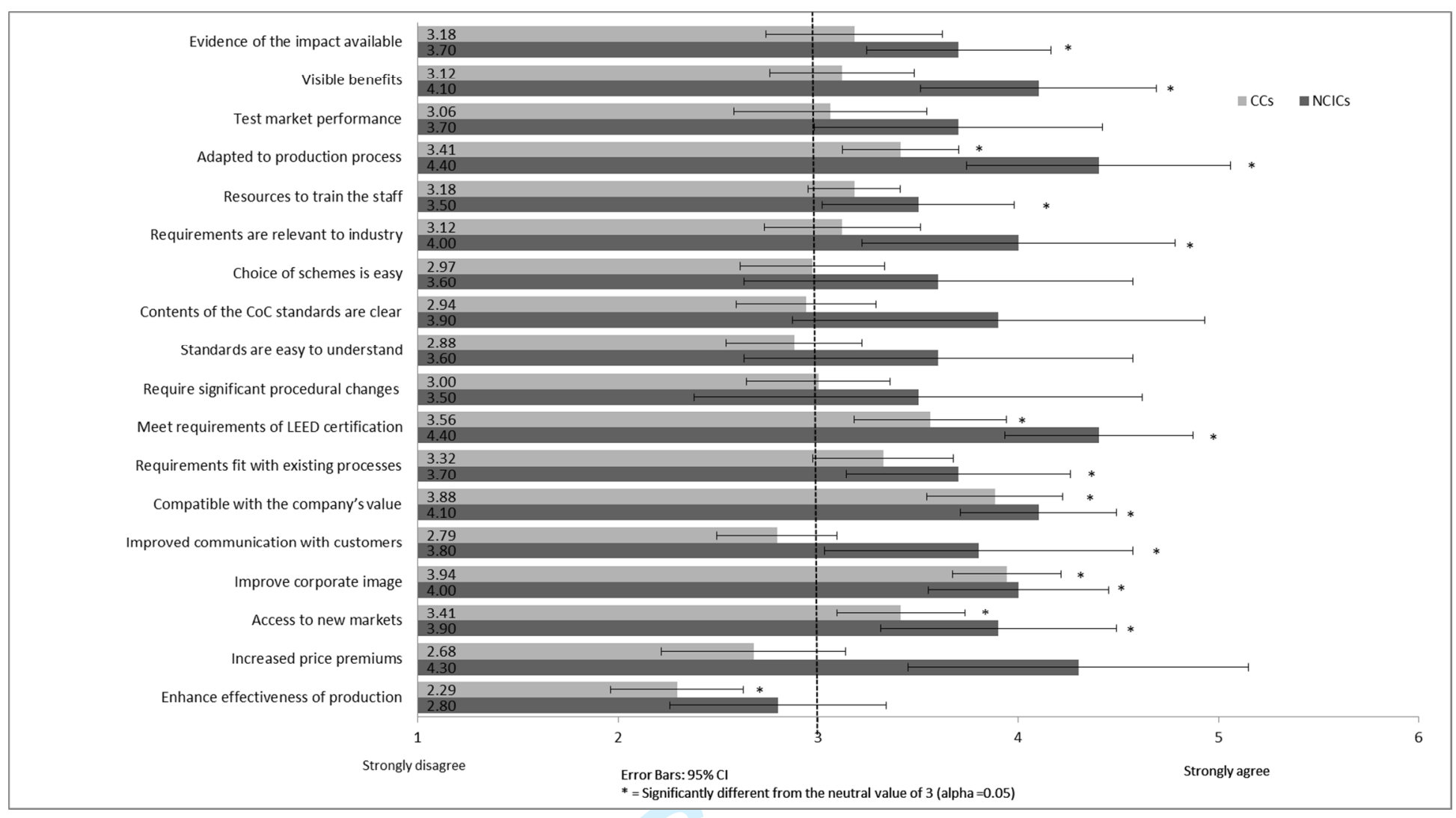

Figure 1: Mean attitudes of certified companies (CCs) and non certified, but interested companies (NCICs) towards CoC certification (including 95\% confidence intervals)

$*$ Significantly different from a neutral level of $3($ alpha $=0.05)$ 


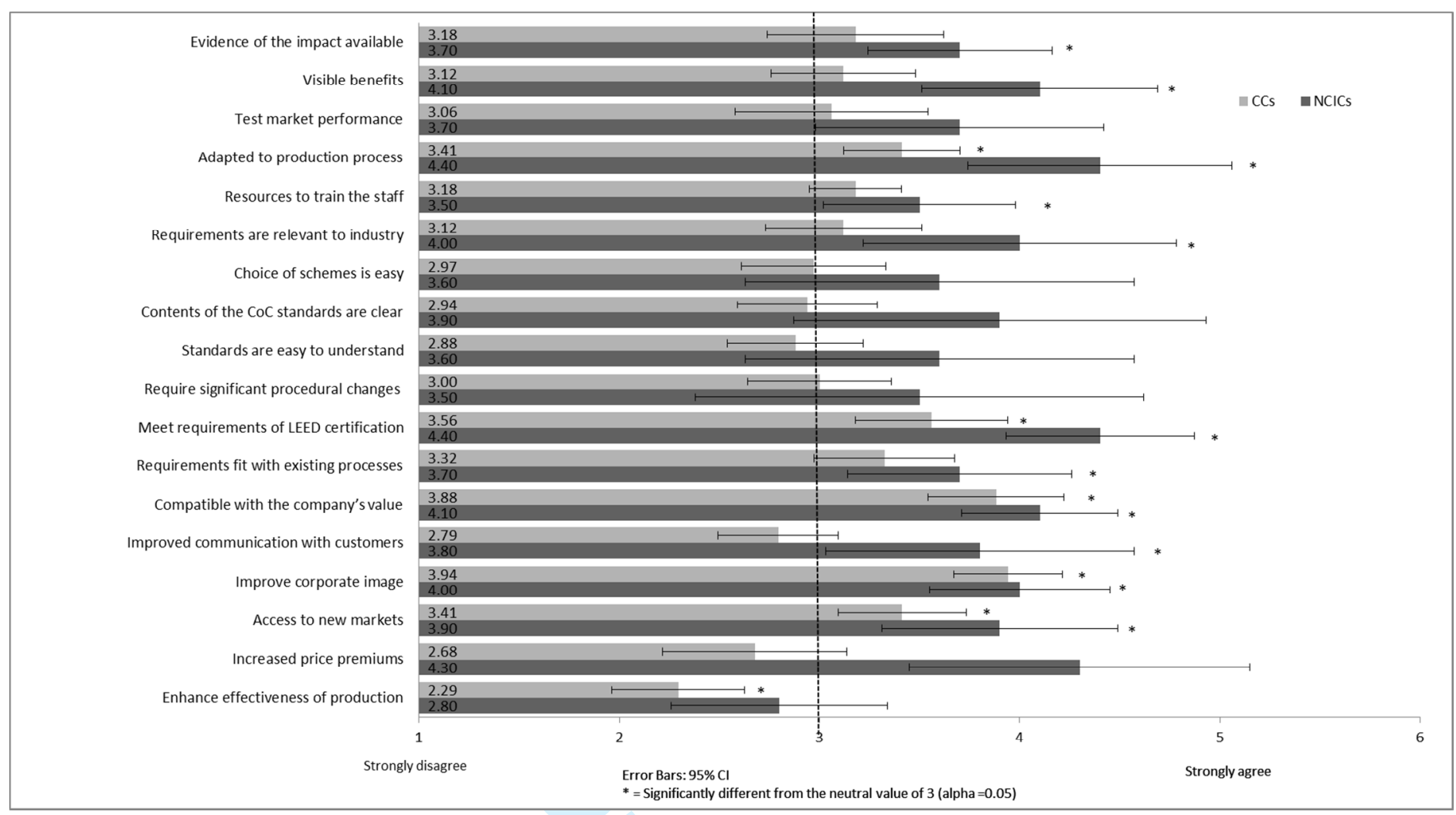

